\title{
SCIENTIFIC REPORTS

\section{OPEN Practical Resistance of Ostrinia nubilalis (Lepidoptera: Crambidae) to Cry1F Bacillus thuringiensis maize discovered in Nova Scotia, Canada}

\begin{abstract}
Jocelyn L. Smith*, Yasmine Farhan \& ArthurW. Schaafsma
Transgenic maize, Zea mays L., modified to express insecticidal proteins from the bacterium Bacillus thuringiensis Berliner, was introduced in 1996 to control Ostrinia nubilalis Hübner (Lepidoptera: Crambidae), a key maize pest in North America. The high-dose/refuge concept, developed to delay or prevent resistance evolution to this technology, has been exemplified by $O$. nubilalis as no cases of practical resistance were identified in $>20$ years. This study documents the first case of practical resistance to Cry1F Bt maize by $O$. nubilalis in North America. Four collections of $O$. nubilalis were made from Cry1F maize in Nova Scotia, Canada with unexpected injury (UXI) ranging from 30-70\%. Greater survival of UXI collections was observed when larvae were exposed to the highest concentration of $200 \mathrm{ng} \mathrm{Cry1F} \mathrm{cm}{ }^{-2}$ in diet-overlay bioassays compared to susceptible laboratory colonies. Larvae also fed and survived on Cry1F leaf tissue in $7 \mathrm{~d}$ bioassays. A collection from non-Bt maize, $120 \mathrm{~km}$ west of the UXI region, also survived $200 \mathrm{ng} \mathrm{Cry} 1 \mathrm{~F} \mathrm{~cm}^{-2}$, but was susceptible to Cry1F leaf tissue. Detection of Cry1F-resistant $O$. nubilalis in what might be considered an insignificant maize-growing region indicates that a number of preventable causal factors may have been related to inadequate stewardship of Bt maize technology.
\end{abstract}

Transgenic maize, Zea mays L., modified to express insecticidal proteins from the bacterium Bacillus thuringiensis Berliner, commonly referred to as Bt maize, has been widely adopted for control of key maize insect pests in North America, since introduced in 1996. In Canada, approximately $85 \%$ of maize acres were planted with Bt maize in $2017^{1}$. In North America, the primary target pest of Bt maize has historically been the European corn borer Ostrinia nubilalis Hübner (Lepidoptera: Crambidae). The distribution of O. nubilalis overlaps with most of the maize-producing regions in the US and Canada ${ }^{2}$. Ostrinia nubilalis is a stalk boring pest whose feeding injury in maize results in yield loss, increased infection of secondary pathogens that cause stalk and ear rots, ear drop, stalk breakage, and lodging, which impedes harvest ${ }^{2}$. The cost of $O$. nubilalis management and incurred yield losses were estimated to exceed $\$ 1$ billion USD before the introduction of Bt maize ${ }^{2}$. Adoption of Bt maize for O. nubilalis control has resulted in widespread suppression of this pest population in North America, providing economic and environmental benefits to both Bt and non-Bt maize producers ${ }^{3,4}$.

The first commercially available Bt maize events, Bt-11 (Syngenta LLC, Research Triangle Park, NC) and MON810 (Monsanto Company, St. Louis, MO) expressing Cry1Ab protein were approved for use in Canada in 1996 and 1997, respectively ${ }^{5,6}$. In 2002, event TC1507 (co-developed by Dow AgroSciences LLC, Indianapolis, IN and Pioneer Hi-Bred International, Johnston, IA) which expresses Cry1F protein was approved in Canada ${ }^{7}$. To delay or prevent resistance to Bt maize, defined as a heritable decrease in susceptibility by the target pest population, insect resistance management (IRM) strategies were developed for implementation by trait providers and growers. The high-dose/refuge (HDR) strategy, which was developed for O. nubilalis, has been the foundation for IRM in North America ${ }^{8}$ and has been adapted for other target pests of Bt maize. A highly toxic protein will kill nearly all ( $>99.9 \%$ ) homozygous susceptible insects and $~ 95 \%$ of heterozygous susceptible insects ${ }^{9}$. A non-Bt refuge is intended to support an unexposed, susceptible portion of the pest population that will mate with rare, 


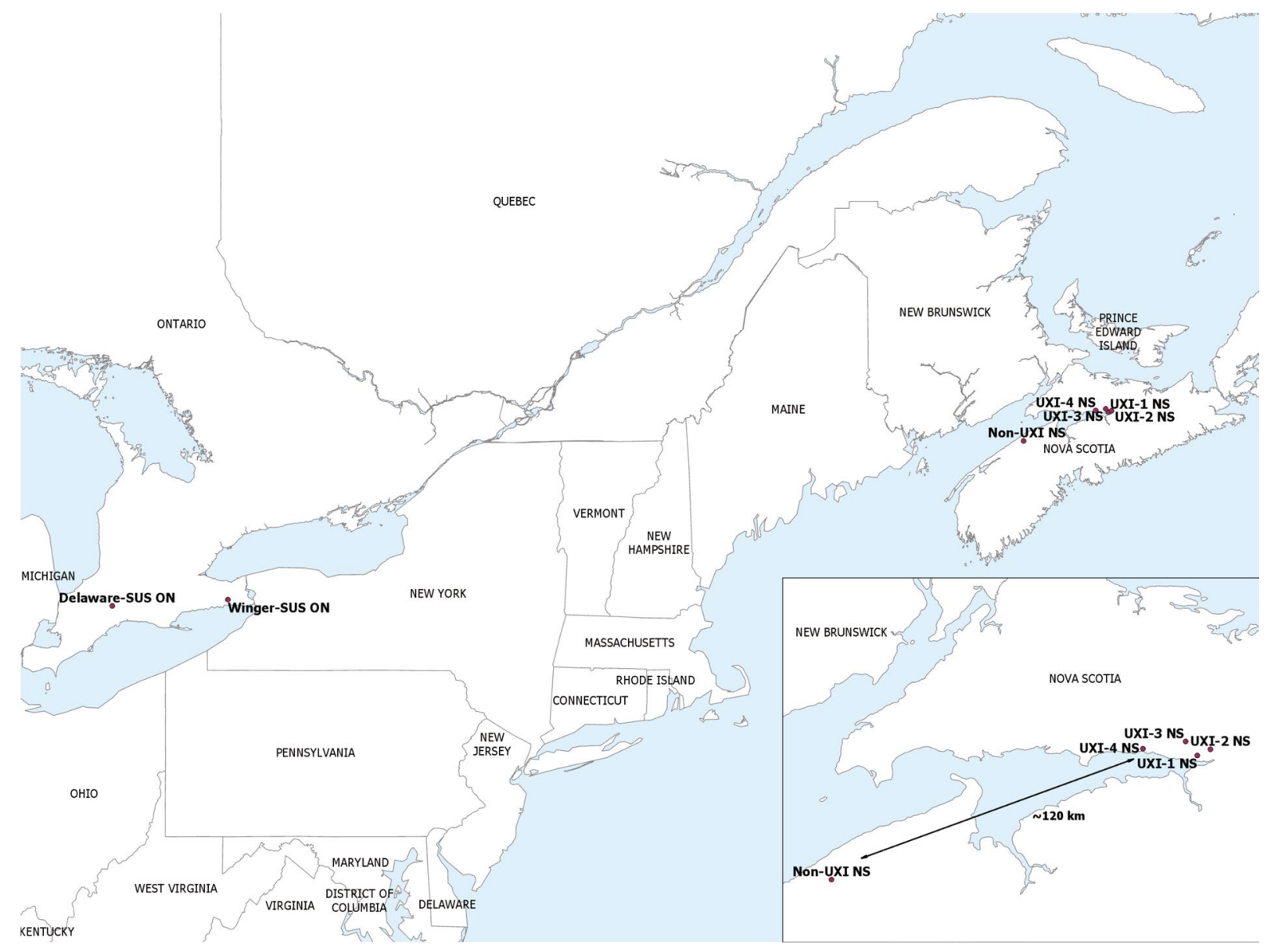

Figure 1. Location of Ostrinia nubilalis collections made from four fields with unexpected injury to Cry1F maize hybrids (UXI-1 to UXI-4) and one field of non-Bt maize (Non-UXI) in 2018 in Nova Scotia (NS), Canada. Susceptible laboratory colonies were collected from Winger and Delaware, Ontario (ON) in 2010 and 2016, respectively.

resistant survivors from the Bt crop, thereby maintaining low numbers of individuals carrying resistance alleles within the population. Models for single high-dose Bt toxins predicted 15-30 years of durability with implementation of $5-20 \%$ refuge ${ }^{10,11}$. The IRM strategy for Bt maize and O. nubilalis has been considered exemplary, as practical resistance, defined as field-evolved resistance that reduces the efficacy of the Bt crop and has practical implications for pest control ${ }^{12}$, has not been documented in Canada (J.L.S., unpublished data) or the U.S. ${ }^{13-16}$. Bt-resistant $O$. nubilalis have only been reported from field collections in North America in two instances to date. A population collected from Minnesota in 2001 survived a diagnostic concentration of Cryl Ab during routine susceptibility monitoring and survived feeding on Cryl Ab leaf tissue; however, larvae were unable to survive on whole plants expressing Cryl $\mathrm{Ab}^{13}$. A collection was identified from Iowa in 2004 that exhibited survival at a diagnostic concentration of Cry1F and survived exposure to Cry1F leaf tissue in assays ${ }^{14}$. Neither case resulted in classification as practical resistance because subsequent monitoring in these regions did not detect reduced susceptibility ${ }^{14}$. Practical resistance to Bt maize has evolved in 15 other lepidopteran pests ${ }^{16}$ in such as Helicoverpa zea L. ${ }^{17}$, Spodoptera frugipera J.E. Smith ${ }^{18}$, and Striacosta albicosta Smith ${ }^{19,20}$, and the coleopteran, Diabrotica spp. LeConte ${ }^{21-23}$, presumably because the high-dose requirement was not met between Bt events and their target pest.

In the fall of 2018, unexpected injury (UXI) by O. nubilalis to a maize hybrid expressing event TC1507 at a number of fields in Nova Scotia, Canada was reported to the authors, only 12 years after Cry1F hybrids were first marketed in the region. The Maritime Province of Nova Scotia is a predominantly bedrock peninsula surrounded by the Atlantic Ocean (Fig. 1). Nova Scotia is a relatively small maize growing region ${ }^{24}$; approximately 14,000 ha were grown in 2018 (G. Murray, personal communication). Collections of O. nubilalis were made from four fields with unexpected injury near Truro, NS and one from a non-Bt field approximately $120 \mathrm{~km}$ west near Kentville, NS. Second generation offspring of the NS field collections were tested for their susceptibility to Cry1F proteins in diet-overlay concentration response bioassays and to Cry $1 \mathrm{~F}$ and Cry1 Ab in leaf tissue bioassays and compared to known susceptible populations of $O$. nubilalis collected from the Province of Ontario, Canada. The results of this investigation confirm that O. nubilalis collected in Nova Scotia are resistant to Cry1F. This is the first case of practical resistance to Cry1F or any Bt protein among O. nubilalis in North America. Although there are many questions surrounding the development of Cry1F resistance in O. nubilalis in what might be considered 


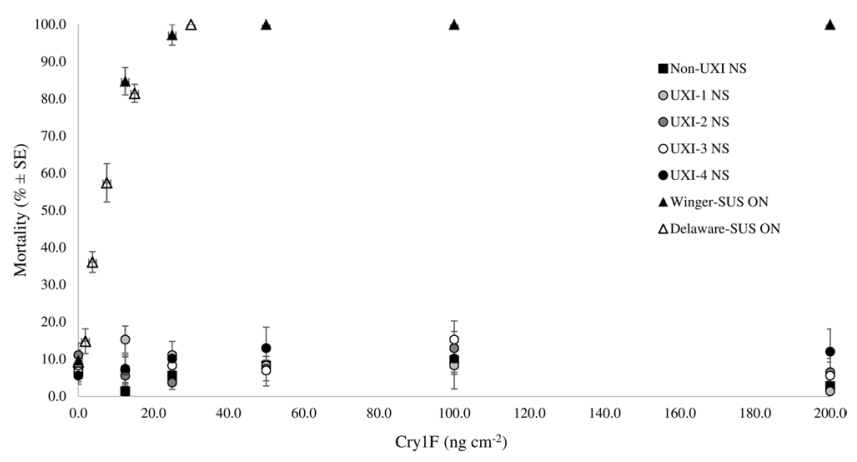

Figure 2. Mortality of neonate ( $<24 \mathrm{hr}$ old) Ostrinia nubilalis exposed to Cry1F protein in diet-overlay bioassays. Larvae were second generation offspring of $O$. nubilalis collected from four fields with unexpected injury to Cry1F maize hybrids (UXI-1 to UXI-4) and one field of non-Bt maize (Non-UXI) in 2018 in Nova Scotia (NS), Canada. Susceptible laboratory colonies were collected from Winger and Delaware, Ontario (ON) in 2010 and 2016, respectively.

\begin{tabular}{|c|c|c|c|c|c|c|c|}
\hline \multirow[b]{2}{*}{ Collection (Province) } & \multirow[b]{2}{*}{$n^{\mathrm{a}}$} & \multirow[b]{2}{*}{ Slope \pm SE } & \multicolumn{3}{|l|}{ Cry1F $\left(\mathrm{ng} / \mathrm{cm}^{2}\right)$} & \multirow[b]{2}{*}{$X^{b}$} & \multirow{2}{*}{\begin{tabular}{|l|}
$\operatorname{Cry1F}\left(\mathrm{ng} / \mathrm{cm}^{2}\right)$ \\
$\mathrm{EC}_{50}(95 \% \mathrm{CI})$ \\
\end{tabular}} \\
\hline & & & $\mathrm{LC}_{50}(95 \% \mathrm{CI})$ & $\mathrm{LC}_{95}(95 \% \mathrm{CI})$ & $\mathrm{LC}_{99}(95 \% \mathrm{CI})$ & & \\
\hline Winger-Sus (ON) & 432 & $3.31 \pm 1.02$ & $6.48(1.66-9.39) \mathrm{a}$ & $20.34(16.30-35.02) a$ & $\begin{array}{l}32.66(23.37-108.58) \\
\text { a }\end{array}$ & 6.48 & $4.43(2.62-6.01) \mathrm{a}$ \\
\hline Delaware-Sus (ON) & 648 & $2.84 \pm 0.29$ & $6.65(5.54-7.74) \mathrm{a}$ & $25.25(20.55-33.54) \mathrm{a}$ & $43.89(33.15-65.79) \mathrm{a}$ & 12.51 & $3.78(2.33-5.93) \mathrm{a}$ \\
\hline Non-UXI (NS) & 432 & $\mathrm{NE}^{\mathrm{c}}$ & $>200 \mathrm{~b}$ & $>200 \mathrm{~b}$ & $>200 \mathrm{~b}$ & $\mathrm{NE}$ & $>200 \mathrm{~b}$ \\
\hline UXI-1 (NS) & 432 & $\mathrm{NE}$ & $>200 \mathrm{~b}$ & $>200 \mathrm{~b}$ & $>200 \mathrm{~b}$ & 10.03 & $>200 \mathrm{~b}$ \\
\hline UXI-2 (NS) & 648 & $\mathrm{NE}$ & $>200 \mathrm{~b}$ & $>200 \mathrm{~b}$ & $>200 \mathrm{~b}$ & $24.53 *$ & $>200 \mathrm{~b}$ \\
\hline UXI-3 (NS) & 432 & $\mathrm{NE}$ & $>200 \mathrm{~b}$ & $>200 \mathrm{~b}$ & $>200 \mathrm{~b}$ & 17.14 & $>200 \mathrm{~b}$ \\
\hline UXI-4 (NS) & 648 & NE & $>200 \mathrm{~b}$ & $>200 \mathrm{~b}$ & $>200 \mathrm{~b}$ & $23.31 *$ & $>200 \mathrm{~b}$ \\
\hline
\end{tabular}

Table 1. Susceptibility and growth inhibition of neonate ( $<24 \mathrm{hr}$ old) Ostrinia nubilalis larvae reared from field collections in Nova Scotia, Canada in 2018 and susceptible laboratory colonies to Cry1F Bacillus thuringiensis insecticidal protein in terms of lethal (LC) or effective concentration (EC) with $95 \%$ confidence intervals (CI) in brackets. Values followed by the same letter within columns are not significantly different based on

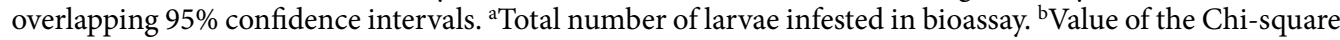
goodness-of-fit test. $* p<0.10$. ${ }^{\mathrm{C}}$ Not estimable due lack of mortality response within the concentration range tested. Concentrations tested were: $0,12.5,25.0,50.0,100.0,200.0 \mathrm{ng}$ Cry1F cm ${ }^{-2}$ for all collections except for Delaware, ON where concentrations tested were: 0, 1.9, 3.8, 7.6, 15.0, 30.0 $\mathrm{ng} \mathrm{Cry1F} \mathrm{cm}^{-2}$.

an insignificant maize growing region, a number of causal factors related to inadequate stewardship of Bt maize technology may have been overlooked by stakeholders in that region.

\section{Results}

Diet bioassays. Greater than $80 \%$ survival was observed among all of the NS UXI collections exposed to the highest concentration of $200 \mathrm{ng}$ Cry $1 \mathrm{~F} \mathrm{~cm}^{-2} 7$ days after introduction (DAI) (Fig. 2). Similarly, more than $95 \%$ of the larvae from the non-UXI site in NS survived the highest concentration (Fig. 2). Due to the lack of a mortality response within the concentration range tested, lethal concentration values for the UXI collections could not be estimated, but exceeded $200 \mathrm{ng} \mathrm{cm}^{-2}$ (Table 1). In contrast, $100 \%$ mortality was observed in the Delaware, ON collection at the highest concentration tested $\left(30 \mathrm{ng} \mathrm{cm}^{-2}\right)$, and for Winger, ON, $97 \%$ mortality was observed at $25 \mathrm{ng} \mathrm{cm}^{-2}$ and no survival was observed at any higher concentration $\left(50-200 \mathrm{ng} \mathrm{cm}^{-2}\right)$. The mortality responses of the Delaware and Winger, ON collections were alike based on overlapping confidence intervals; $\mathrm{LC}_{50}$ values were 6.7 and $6.5 \mathrm{ng} \mathrm{cm}^{-2}$, respectively (Table 1 ).

Leaf tissue bioassays. Proportional survival of O. nubilalis larvae on Cry1F or Cry1 Ab leaf tissue depended on the interaction among treatment, collection, and DAI $\left(\mathrm{F}_{12,2330}=11.31, p<0.0001\right)$. At $2-3$ DAI, survival of UXI collections on Cry1F tissue ranged from 66-84\%; survival of the non-UXI collection, and susceptible Ontario colonies was 23, 7 and 22\%, respectively (Fig. 3). Survival on Cry1Ab tissue at 2-3 DAI ranged from $37-72 \%$ among UXI collections, 35\% for non-UXI, and 2 and $8 \%$ of Ontario colonies (Fig. 3). By 4-5 DAI, survival of UXI collections declined to $30-63 \%$ on Cry1F tissue (Fig. 2). Neither of the Ontario collections nor the non-UXI collection survived on Cry1F or Cry1 Ab tissue beyond 4-5 DAI (Fig. 3). On Cry1Ab tissue, survival among UXI collections ranged from 1-3\% at 4-5 DAI. No survival of any collection was observed on Cry $1 \mathrm{Ab}$ tissue by 7 DAI (Fig. 3). At 7 DAI, 36-66\% of larvae from the UXI collections were still alive, except UXD-3 which had $<10 \%$ survival (Fig. 3 ). 


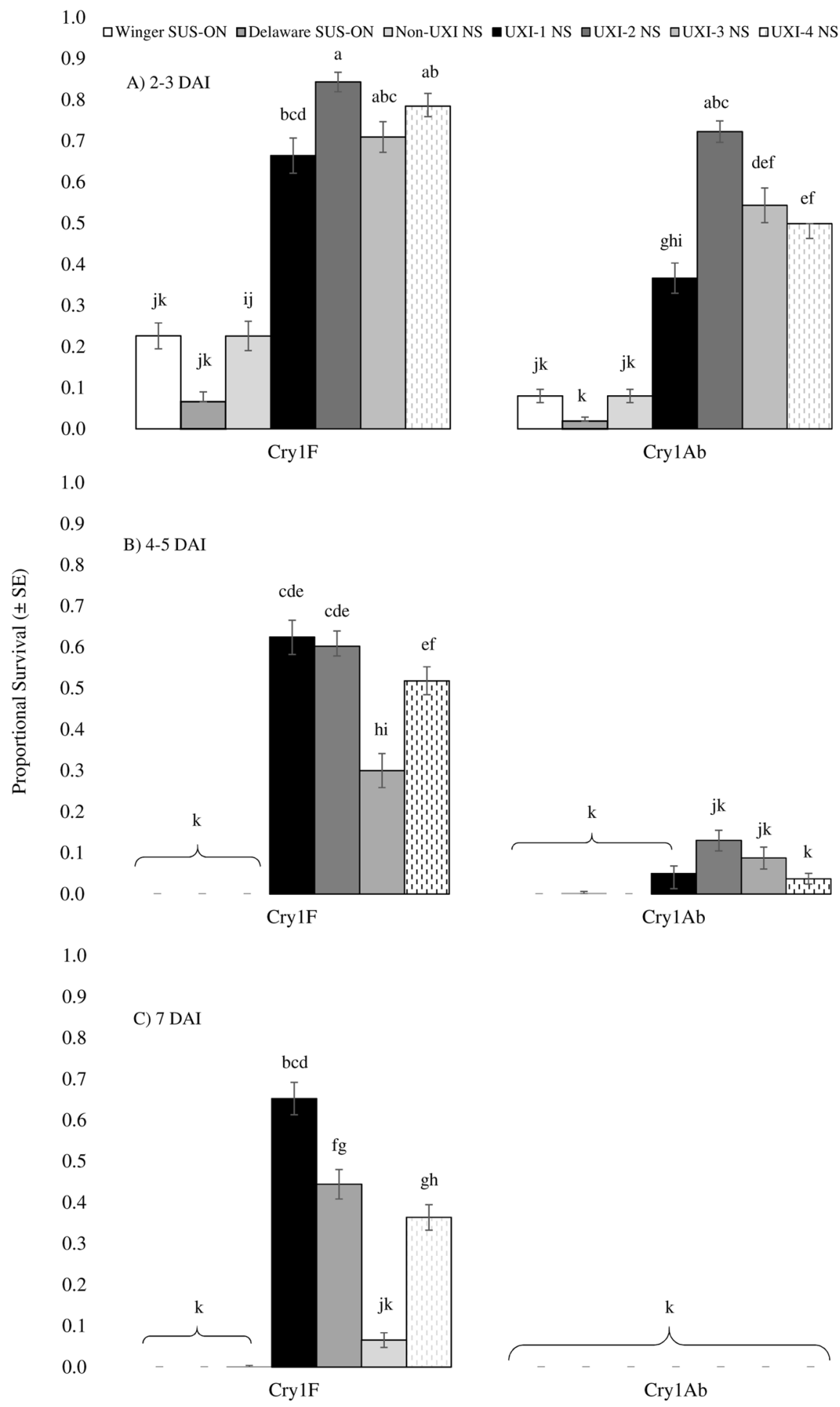

Figure 3. Mean proportional survival $\pm \mathrm{SE}$ of neonate ( $<24 \mathrm{hr}$ old) Ostrinia nubilalis larvae in Cry1F or Cry1Ab maize leaf tissue bioassays at (A) 2-3, (B) 4-5, and (C) 7 days after introduction (DAI). Larvae were second generation offspring of $O$. nubilalis collected from four fields with unexpected injury to Cry1F maize hybrids (UXI-1 to UXI-4) and one field of non-Bt maize (NON-UXI) in 2018 in Nova Scotia (NS), Canada. Susceptible laboratory colonies were collected from Winger and Delaware, Ontario (ON) in 2010 and 2016, respectively. Means with the same letter are not significantly different (Tukey's HSD test, $p>0.05$ ).

Percent defoliation of Cry1F and Cry1 Ab leaf tissue also depended on the interaction among treatment, collection, and DAI $\left(\mathrm{F}_{12,1947}=20.44, p<0.0001\right)$. On all sampling dates, larvae from UXI collections consumed more leaf tissue than the non-UXI collection and susceptible Ontario colonies, and UXI collections consumed more 

25.0

$$
\text { A) 2-3 DAI }
$$

20.0
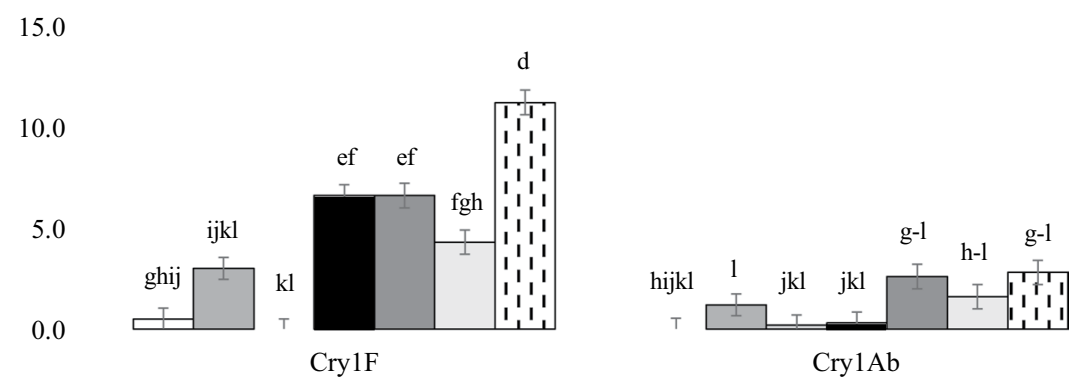

25.0

B) 4-5 DAI
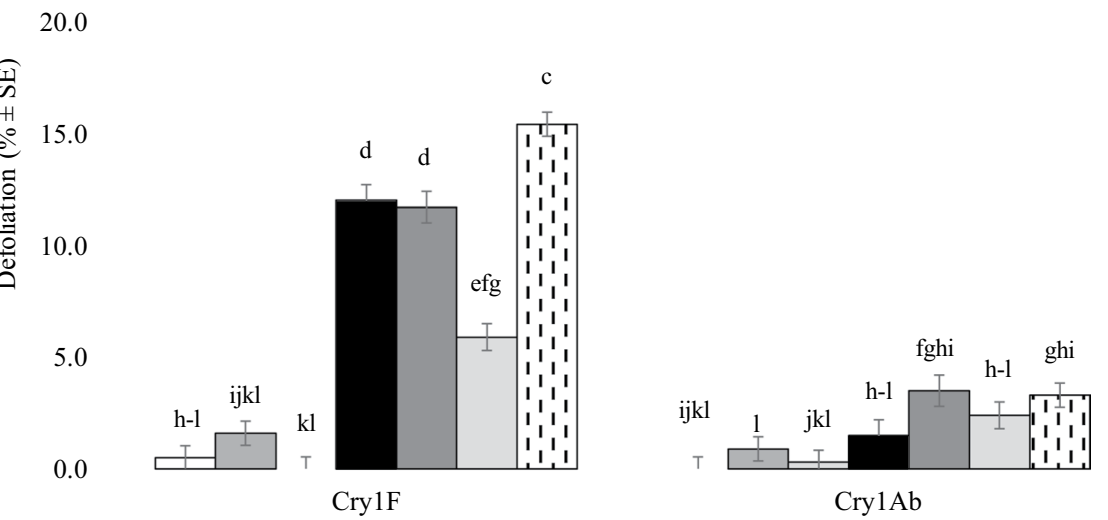

25.0

C) 7 DAI

20.0

15.0

10.0

5.0

0.0

a

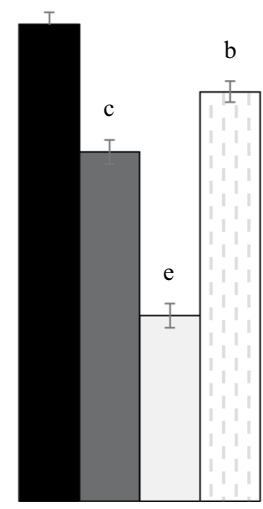

CrylF

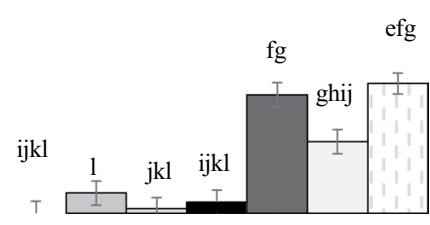

Cry1 Ab

Figure 4. Mean percent defoliation $\pm \mathrm{SE}$ of CrylF or Cryl Ab maize leaf tissue by Ostrinia nubilalis larvae at (A) 2-3, (B) 4-5, and (C) 7 days after introduction (DAI). Larvae were second generation offspring of $O$. nubilalis collected from four fields with unexpected injury to Cry1F maize hybrids (UXI-1 to UXI-4) and one field of non-Bt maize (NON-UXI) in 2018 in Nova Scotia (NS), Canada. Susceptible laboratory colonies were collected from Winger and Delaware, Ontario (ON) in 2010 and 2016, respectively. Means with the same letter are not significantly different (Tukey's HSD test, $p>0.05$ ).

Cry1F than Cry1Ab leaf tissue (Fig. 4). Larvae from susceptible collections and the non-UXI collection never consumed more than $2 \%$ of the Cry $1 \mathrm{~F}$ or Cry1 Ab leaf tissue provided. By $7 \mathrm{DAI}$, larvae from UXI collections had consumed $8-21 \%$ of Cry1F leaf tissue (Fig. 4). 


\section{Discussion}

This study documents the first case of practical resistance to Bt maize among O. nubilalis in North America. Observations of Cry1F hybrids with 30-70\% injury by O. nubilalis in Nova Scotia in 2018 and survival of offspring on Cry1F leaf tissue in laboratory bioassays provide evidence that practical resistance to Cry1F has developed among O. nubilalis in Nova Scotia. Furthermore, offspring of these field collections survived exposure to a concentration of $200 \mathrm{ng}$ Cry $1 \mathrm{~F} \mathrm{~cm}^{-2}$ in diet-overlay bioassays which is much higher than the diagnostic concentration of $60 \mathrm{ng}$ Cry1F cm ${ }^{-2}$ for Cry1F resistance, derived from extensive testing of U.S. O. nubilalis populations ${ }^{25,26}$. There are no previously reported data on the susceptibility of O. nubilalis in Nova Scotia to any $\mathrm{Bt}$ proteins. The lack of baseline susceptibility data from this region highlights the limitations of historical susceptibility monitoring efforts and the ability to identify field-evolved resistance; however, unexpected injury to $\mathrm{Bt}$ maize has not been previously reported in this region. Nova Scotia populations of O. nubilalis collected in 2018 were compared with those collected in Ontario in 2010 and 2016 that have been maintained as laboratory colonies shown to be susceptible to Cry1F protein in this study. Since $\mathrm{LC}_{50}$ values for Cry1F could not be estimated for Nova Scotia O. nubilalis, resistance ratios $(\mathrm{RR})$ of $\mathrm{LC}_{50}$ values of Nova Scotia and susceptible laboratory colonies could not be calculated. A pest population is generally considered resistant when its $\mathrm{LC}_{50}$ value is 10 times greater than the $\mathrm{LC}_{50}$ value of a comparable susceptible population ${ }^{27}$. In this study, the $\mathrm{LC}_{50}$ values of Nova Scotia populations would have needed to exceed $51-65 \mathrm{ng}$ Cry $1 \mathrm{~F} \mathrm{~cm} ~^{-2}$ for a $\mathrm{RR}>10$ which is plausible given the greatest mean mortality observed at $200 \mathrm{ng} \mathrm{cm}^{-2}$ was $18.5 \%$.

In addition to requiring a high-dose and non-Bt refuge, the HDR strategy relies on a number of assumptions, including that the frequency of resistance alleles within a population are low $\left(<10^{-3}\right)$, that resistance is recessive, and that random mating occurs between susceptible and resistant insects ${ }^{28} . \mathrm{F}_{1}$ and $\mathrm{F}_{2}$ screening of O. nubilalis from the Midwestern U.S. from 2003 to 2009 determined that Cry1F resistance allele frequencies were higher than $10^{-326}$. As allele frequencies did not change significantly during the years of that study, it was suggested that this may have reflected the frequency of alleles within O. nubilalis populations before the introduction of Cry1F maize ${ }^{26}$. In contrast, allele frequencies for Cry1 Ab resistance were found to be very rare among O. nubilalis collected in France and the U.S. ${ }^{29}$. In laboratory selection experiments, a Cry1F-resistant colony of O. nubilalis was developed with 3000 -fold resistance after 35 generations of selection ${ }^{25}$. Experiments with the laboratory-selected colony and the Iowa field collection showed that a high level of Cry1F resistance was controlled by an autosomal, single locus, recessive factor with weak fitness costs ${ }^{30,31}$.

The results of this study indicate that the four UXI collections from the Truro, NS region have developed greater tolerance to Cry1F than the non-UXI collection taken from non-Bt maize near Kentville, NS. Although all NS collections exhibited tolerance to Cry1F at $200 \mathrm{ng} \mathrm{cm}^{-2}$ in diet-overlay bioassays, the UXI collections had greater survival and caused greater defoliation than the non-UXI collection in leaf tissue bioassays. Similarly, the laboratory-selected Cry1F-resistant strain of $O$. nubilalis described by Pereira et al. ${ }^{31}$ was able to survive concentrations of $>12,000 \mathrm{ng}^{\mathrm{Cry} 1 \mathrm{~F} \mathrm{~cm}} \mathrm{~cm}^{-2}$ in diet-overlay bioassays ${ }^{25}$; however, survival on vegetative Cry1F leaf tissue was approximately $20 \%$ lower than on non-Bt isoline tissue. Our leaf tissue bioassay results demonstrated variability in susceptibility among collections from UXI fields which suggests that three of the UXI collections may be homozygous resistant to Cry1F and that the UXI-3 and non-UXI collections may remain heterozygous susceptible, as the dose of Cry1F expressed in leaf tissue has been shown to be high enough to kill or significantly inhibit the development of heterozygotes ${ }^{31}$. Variability of Cry1F expression among maize tissues ${ }^{32}$ may also impact the development and detection of resistance as the dose expressed in vegetative stage plants may be higher than in reproductive stage plants, as Pereira et al. ${ }^{31}$ observed greater survival of Cry1F-resistant larvae on R1 stage maize than vegetative stage maize. A short-coming of our study is that a non-Bt near-isoline was unavailable for use as a negative control in the leaf tissue bioassay. Without collaboration with Bt crop developers, public researchers are restricted to using commercially available corn hybrids of which Bt and non-Bt isolines are very rare. Moreover, testing of $O$. nubilalis collected in this study against the Bt crop developers' Cry1F protein was not permitted, however, we were able to obtain Cry1F protein from a public source.

With violation of the assumption that Cry1F resistance alleles in O. nubilalis populations are rare, the functionally recessive nature of $\mathrm{Cry} 1 \mathrm{~F}$ resistance indicates that implementation of refuge is critical to maintaining $O$. nubilalis susceptibility to Cry1F by production of susceptible insects to mate with potentially resistant ones ${ }^{14,31}$. Since 2005, industry has moved towards Bt maize products that express a pyramid of two or more high-dose toxins targeting $O$. nubilalis to prolong Bt event durability with smaller refuge requirements that are more likely to be implemented by growers ${ }^{10}$. The likelihood of resistance development to a pyramid of high-dose toxins is lower than to a single toxin; however the risk increases when single toxin hybrids are not removed from the market and selection pressure is sustained ${ }^{33,34}$. In the Nova Scotia case, information obtained from maize producers and seed providers in the region where resistant populations have been found, confirm that maize hybrids expressing only Cry $1 \mathrm{~F}$, rather than a pyramid of toxins targeting $O$. nubilalis, were used extensively since 2006 up to and including 2018. Although a $20 \%$ structured refuge is typically required for single toxin Bt maize products in $\mathrm{Canada}^{35}$, data on compliance with this requirement are not available from the region in question. The Canadian Food Inspection Agency, the federal body responsible for regulation of plants with novel traits (PNT) requires that IRM plans are developed for each approved PNT; however, Bt crop developers are responsible for monitoring grower compliance to IRM requirements ${ }^{36}$. Assuming that the frequency of Cry1F resistance alleles within the Nova Scotia O. nubilalis populations was similar to that found in U.S. populations ${ }^{25}$, a lack of non-Bt refuge may have facilitated the development of this resistant population.

In addition to the selection pressure placed on O. nubilalis populations in this region due to the use of a single Bt toxin, the geographic characteristics of this region should be investigated for their contribution to resistance development. The phenology of $O$. nubilalis in the Maritimes region of Canada is not well understood. Determination of the pheromone races, voltinism, distribution, and host range of $O$. nubilalis populations in this region would provide greater understanding of the historical isolation or mixing of $O$. nubilalis under Cry $1 \mathrm{~F}$ 


\begin{tabular}{|l|l|l|l|l|l|l|}
\hline Collection & $\begin{array}{l}\text { Nearest } \\
\text { town }\end{array}$ & $\begin{array}{l}\text { Planting } \\
\text { date }\end{array}$ & $\begin{array}{l}\text { Plants with injury } \\
\text { by } \text { O. nubilalis (\%) }\end{array}$ & $\begin{array}{l}\text { Collection } \\
\text { date }\end{array}$ & $\begin{array}{l}\text { No. larvae used to } \\
\text { initiate colony }\end{array}$ & $\begin{array}{l}\text { Generation used in } \\
\text { bioassays }\end{array}$ \\
\hline Nova Scotia \\
\hline NON-UXI & Kentville & $\begin{array}{l}24 \text { May } \\
2018\end{array}$ & 60 & 6 Sept 2018 & 131 & F2 \\
\hline UXI-1 & Truro & $\begin{array}{l}16 \text { May } \\
2018\end{array}$ & 70 & 4 Sept 2018 & 239 & F2 \\
\hline UXI-2 & Truro & $\begin{array}{l}16 \text { May } \\
2018\end{array}$ & 30 & 4 Sept 2018 & 75 & F2 \\
\hline UXI-3 & Truro & 9 May 2018 & 40 & 4 Sept 2018 & 193 & F2 \\
\hline UXI-4 & Truro & $\begin{array}{l}12 \text { May } \\
2018\end{array}$ & 30 & 5 Sept 2018 & 57 & F2 \\
\hline Ontario Susceptible Laboratory Colonies & & 22 Nov 2010 & 41 & F95 \\
\hline Winger-Sus & Winger &. &. & 6 Oct 2016 & 19 & F17 \\
\hline Delaware-Sus & Delaware &. &. &
\end{tabular}

Table 2. Location and collection information of Ostrinia nubilalis collected in Nova Scotia in 2018 and Ontario in 2010 and 2016 for use in Bt susceptibility bioassays.

selection pressure and the probability of successful mitigation of Cry1F resistance in this region. Using a similar recent case for mitigation of a Cry1F-resistant population of Diatraea grandiosella Dyar detected in Arizona ${ }^{37}$, a number of strategies should be implemented immediately in the Maritimes region and in neighbouring provinces and states such as New Brunswick, Prince Edward Island, Quebec, Maine, New York, New Hampshire, and Vermont to reduce the size and spread of Cry1F-resistant O. nubilalis populations.

The sale and planting of Bt maize hybrids expressing only Cry1F should cease immediately to discourage survival of resistant individuals. Maize producers should only plant hybrids expressing a pyramid of at least two $\mathrm{Bt}$ toxins that $\mathrm{O}$. nubilalis remain susceptible to. Although cross-resistance between Cry1F and Cry1 Ab has not been documented previously ${ }^{25}$, Bt hybrids expressing only Cry1 Ab, pyramids expressing Cryl Ab and Cry1F, or Cry1 Ab and Vip3A, should not be used, to decrease selection pressure against Cry1 Ab. Elevated survival of NS UXI collections on Cry1 Ab leaf tissue compared to susceptible laboratory colonies and the non-UXI collection at 2-3 DAI was observed in this study; therefore further determination of the susceptibility of the Cry1F-resistant collections to Cryl Ab is needed.

In fields where unexpected injury to Cry1F maize has occurred, maize stalks should be chopped and buried using tillage in the fall to reduce the frequency of resistance alleles in $O$. nubilalis populations ${ }^{38}$. Cry $1 \mathrm{~F}$ resistance has not been shown to be associated with strong fitness costs in O. nubilalis, therefore, survival rates of homozygous susceptible, heterozygous resistant, and homozygous resistant O. nubilalis from non-Bt plants may not differ significantly ${ }^{30}$. As shown by Pereira et al., very few heterozygous resistant $O$. nubilalis are able to survive on reproductive stage Cry1F plants ${ }^{31}$; therefore, destruction of a significant source of resistant alleles in the overwintering phase will aid in mitigating the resistant population. Lastly, collections of $O$. nubilalis from neighbouring provinces and states should be tested to determine the spread of CrylF-resistant populations. This case highlights the importance of monitoring Bt susceptibility of $O$. nubilalis populations in potentially geographically isolated regions where this technology is deployed, especially where single-toxin maize products are grown. We encourage diligence on the part of regulatory and industry stakeholders to increase monitoring efforts for susceptibility of $O$. nubilalis populations and unexpected injury to Bt maize for similar regions, and discontinue the use of non-pyramided Bt-maize products.

\section{Methods}

Insect collections. Four fields with unexpected injury (UXI) by O. nubilalis to maize hybrids expressing Cry $1 \mathrm{~F}$ protein were visited by the author in early September 2018 after identification by the grower (Fig. 1, Table 2). Seed sales representatives visited the fields in question during the previous week and confirmed Cry $1 \mathrm{~F}$ expression using QuickStix for Cry1F protein (EnviroLogix, Inc., Portland, ME). Additionally, a non-Bt maize field near Kentville, NS, approximately $120 \mathrm{~km}$ west and upwind of the UXI fields, infested with O. nubilalis, was visited within the same week to make a collection of $O$. nubilalis from a site lacking Cry1F exposure (Fig. 1, Table 2). The level of infestation was estimated at each site by counting the number of plants exhibiting symptoms of O. nubilalis injury within 100 examined; across all sites, plants ranged from the R3 (milk) to R5 (dent) stage ${ }^{39}$ (Table 2). Symptomatic plants were cut into sections using pruning shears and placed into mesh bags and shipped to the laboratory at the University of Guelph in Ridgetown, ON, which were received within 4 days of collection. The expression of Cry1F protein was re-confirmed in leaf tissue from a random subsample of five stalks per field using QuickStix for Cry1F protein; all plants from UXI fields tested positive for Cry1F. Stalks were carefully split, larvae were extracted, and placed into tubs containing meridic diet (Table 2$)^{40}$. Rearing conditions were $26: 18^{\circ} \mathrm{C}$, $60 \% \mathrm{RH}$, and photoperiod of 16:8 (L: D) h for all life stages. Larvae pupated in a corrugated cardboard ring, and the ring was transferred to a cage $(30 \mathrm{~cm} \times 30 \mathrm{~cm} \times 60 \mathrm{~cm}$, mesh roof $)$ at the first sign of adult eclosion. Adults were provided with a water source via paper towel wicking ad libitum, and the cage sides were misted with water daily. Wax paper sheets were placed over the cage roof as an oviposition substrate, replaced daily, and placed into a plastic sweater box with moistened paper towel. Colonies of $O$. nubilalis originally collected from Winger and Delaware, ON in 2010 and 2016, respectively, and maintained for 95 and 17 generations, respectively, were used as susceptible laboratory controls for all experiments (Table 2). 
Diet bioassays. Diet used for bioassays was formulated in the same manner as that used for rearing. One $\mathrm{mL}$ of diet per well was dispensed into 128-well bioassay trays (Bio-16, CD International, Pitman, NJ) using a repeater pipette. The diet surface area was $2.0 \mathrm{~cm}^{2}$. Wells were covered with transparent, adhesive, ventilated covers (Frontier Agricultural Sciences, Newark, DE) after diet had solidified. Trays were stored at $4{ }^{\circ} \mathrm{C}$ until required for bioassays. Lyophilized protein standard containing $100 \%$ purity truncated Cry $1 \mathrm{~F}$ was obtained from M. Pusztai-Carey (Case-Western University, Cleveland, $\mathrm{OH}$ ). The protein standard was stored at $-80^{\circ} \mathrm{C}$ inside a desiccator (Desi-Vac Container ${ }^{\mathrm{TM}}$, Thermo Fisher Scientific, Hampton, NH) containing dessicant (Drierite, W.A. Hammond Drietite Co. Ltd., Xenia, OH). CrylF protein solutions were diluted in series from the stock solution using $10 \mathrm{mM}$ CAPS (3-cyclohexylamino)-1-propane sulfonic acid) buffer solution with $\mathrm{pH}$ adjusted to 10.5 using $10 \mathrm{~N} \mathrm{NaOH}$. Five concentrations plus a negative control were used for each bioassay. The concentrations tested for all collections included: $0,12.5,25,50,100$, and $200 \mathrm{ng} \mathrm{cm}^{-2}$ except for Delaware-Sus ON where the concentrations tested were: $0,1.9,3.8,7.6,15.0$, and $30.0 \mathrm{ng} \mathrm{cm}^{-2}$; the negative control was treated with $10 \mathrm{mM}$ CAPS buffer solution. The appropriate concentration of Bt protein or control solution was applied to the diet surface of each well in $30 \mu \mathrm{l}$ aliquots using a repeater pipette.

Trays were repeatedly tilted in all directions to cover the entire diet surface with solution. Trays were left in a fume hood until the solvent component of the solution had evaporated. One unfed, neonate ( $<24 \mathrm{~h}$ old) larva was transferred from the plastic sweater box to each well of the bioassay tray using a fine-point paint brush. Tray covers were replaced following introduction, placed into rearing conditions and covered with cardboard to prevent positive phototaxis and condensation build-up. For each bioassay, 24 or 36 larvae were treated per concentration. Larval mortality and individual larval weight were recorded at 7 DAI. Severely stunted larvae that were alive but weighed less than $0.1 \mathrm{mg}$ were considered dead. Each bioassay was repeated 3 times for each collection.

Leaf tissue bioassays. The maize hybrid P72-11HR which expressed Cry1F was purchased from Pioneer Hi-Bred (Chatham, ON) and the hybrid HZ3011A which expressed Cryl Ab was purchased from Horizon Seeds (Courtland, ON). A non-Bt near-isoline was not available for either hybrid to use as a negative control. Before germination, Bt expression was verified from each seed lot by testing every $16^{\text {th }}$ seed selected for planting using QuickStix for Cry1F protein. Seeds were commercially pre-treated with insecticide and fungicide treatments; therefore, all seeds were washed following the methods of Gassmann et al. ${ }^{21}$ before germination. Seeds were germinated on moistened filter paper in a growth room at $26^{\circ} \mathrm{C}, 60-70 \% \mathrm{RH}$, photoperiod of 16:8 (L:D) h. Once germinated, individual seeds were planted $2 \mathrm{~cm}$ deep in nursery plug pots (Stuewe and Sons, Inc., Corvallis, OR) with moistened soil for 7-10 d. At the VE stage, plants were transferred to the greenhouse and transplanted into black 8-L plastic pots containing a moistened soil-less mixture prepared from a 1:1 blend of Juniper Pro-Line all-purpose mix (JVK, St. Catherines, ON) and Gro-Coir \#3 (Gro-Bark Limited, Waterloo, ON). Each pot was planted with three seedlings of either treatment and pot placement was randomized under the light bank. Plants were grown in a greenhouse (mean daily $\mathrm{T} \pm \mathrm{SD}=25 \pm 3^{\circ} \mathrm{C}$; mean daily $\mathrm{RH} \pm \mathrm{SD} 52 \pm 10 \%$ ) under natural light supplemented by high-pressure sodium lamps (400 W S51 Lumalux ${ }^{\circledR}$, Osram Sylvania, Mississauga, Ontario) placed $120 \mathrm{~cm}$ above the greenhouse bench, with each lamp covering $2 \mathrm{~m}^{2}$, at a photoperiod of 16:8 h L:D. Two weeks after planting, pots were fertilized weekly with $100 \mathrm{~mL}$ of Peters Excel 15-5-15 Cal-Mag Special (JVK, St. Catherines, $\mathrm{ON}$ ) at a concentration of $4 \mathrm{mg} \mathrm{mL}^{-1}$. Individual pots were watered as required.

Maize tissues were collected from the greenhouse on the day of bioassay tray preparation. Wells within a 32-well bioassay tray (CD-32, CD International, Pitman, NJ) were filled with $2.5 \mathrm{~mL}$ of $2.5 \%$ agar. A $9 \mathrm{~cm}^{2}$ piece of filter paper (P5 grade, Fisherbrand ${ }^{\mathrm{TM}}$ ) was placed on the agar, and once fully moistened by the agar solution, a $4 \mathrm{~cm}^{2}$ piece of V6 stage maize leaf tissue was placed into each well. Expression of Bt events was confirmed in each leaf used in the assay before tissue was placed in the bioassay trays using QuickStix for Cry1F protein. Sixteen wells were treated with Cry1F or CrylAb leaves per replicate. Five, unfed, neonate ( $<24 \mathrm{hr}$ old $)$ larvae were placed onto the leaf tissue in each well, transferred from the plastic sweater box using a fine-point paint brush. Transparent, adhesive, ventilated lids were placed over each well (Frontier Agricultural Sciences, Newark, DE). Infested trays were placed into rearing conditions for the duration of the experiment and covered with cardboard. New tissue was added to each well every $2-3 \mathrm{~d}$ to ensure fresh, unlimited food. For each bioassay, 80 larvae were exposed to each treatment and each bioassay was replicated at least 4 times for each collection. At $2-3,4-5$, and 7 DAI, survival and defoliation were assessed. Survival was assessed by gently prodding larvae with a fine-tipped paint brush; larvae that did not respond with movement were considered dead. The number of larvae surviving at each time point was divided by the initial number of larvae infested to calculate proportional survival. Percent defoliation was assessed visually as the area of leaf tissue consumed by the larvae.

Statistical analysis. Diet bioassays. Only diet bioassays with $\geq 80 \%$ survival in the control were used in the analysis. Mortality data were analyzed to determine $\mathrm{LC}_{50}, \mathrm{LC}_{95}$, and $\mathrm{LC}_{99}$ values (concentration of Bt protein that resulted in mortality of 50,95, and $99 \%$ of the individuals in a collection, respectively) with $95 \%$ confidence intervals and slope of the concentration-response curve using PROC PROBIT in SAS 9.4 (SAS Institute, Cary, NC). The OPTC option was used which estimated the natural response rate of larvae in the control ${ }^{41}$. Pearson's chi-square test was used to test the fit of observed values compared to the predicted probit model; results were rejected if $p<0.10^{42}$. Weights of surviving larvae from each concentration were pooled to determine the mean weight per larva and transformed to percent growth inhibition relative to the mean weight of larvae in the control. To determine the $\mathrm{EC}_{50}$ (concentration of Bt protein that inhibits growth in 50 of the individuals in a collection) for each collection, growth inhibition data were analyzed by nonlinear regression fitted to a probit model using a SAS program written by D. Travnicek (Department of Biometry, University of Nebraska-Lincoln) ${ }^{43}$. Pairwise comparisons among collections were made between $\mathrm{LC}_{50}$ values and significant differences were declared for non-overlapping $95 \%$ confidence intervals. 
Leaf tissue bioassays. The effects of treatment, collection, DAI, and their interactions on proportional survival and percent defoliation were analyzed as a generalized linear mixed model using PROC GLIMMIX in SAS 9.4. Replication, replication by treatment, and well within replication by treatment were considered random effects. Dependent variables were treated as repeated measures as observations were taken from wells within replication by treatment at $2-3,4-5$, and 7 DAI. PROC UNIVARIATE and the Shapiro-Wilk statistic were used to test residuals for normal distribution and studentized residuals were calculated to test for outliers using Lund's test ${ }^{42}$. Proportional survival and percent defoliation followed a normal distribution and no outliers were detected. Least squares means (LSMEANS) were estimated and pairwise comparisons were made using Tukey-Kramer tests $(\alpha=0.05)$.

\section{Data availability}

The datasets generated and/or analysed during the current study are available from the corresponding author on reasonable request.

Received: 27 May 2019; Accepted: 7 November 2019;

Published online: 03 December 2019

\section{References}

1. Dunlop, G. 2017 Bt Corn IRM Compliance in Canada. (CropLife Canada, 2018).

2. Mason, C. E. et al. European corn borer ecology, management, and association with other corn pests. (North Central Regional Extension Publication No. NCR 0327, 2018).

3. Hutchison, W. D. et al. Areawide suppression of European corn borer with Bt maize reaps savings to non-Bt maize growers. Science 330, 222-225 (2010).

4. Dively, G. P. et al. Regional pest suppression associated with widespread Bt maize adoption benefits vegetable growers. Proc. Natl. Acad. Sci. USA 115, 3320-3325, https://doi.org/10.1073/pnas.1720692115 (2018).

5. Canadian Food Inspection Agency. DD1996-12: Determination of Environmental Safety of Northrup King Seeds' European Corn Borer (ECB) Resistant Corn (Zea mays L.), http://www.inspection.gc.ca/plants/plants-with-novel-traits/approved-under-review/decisiondocuments/dd1996-12/eng/1303862914603/1303863058362 (1996).

6. Canadian Food Inspection Agency. DD1997-19: Determination of the Safety of Monsanto Canada Inc.'s Yieldgard ${ }^{\mathrm{TM}}$ Insect Resistant Corn (Zea mays L.) Line MON810, http://www.inspection.gc.ca/plants/plants-with-novel-traits/approved-under-review/decisiondocuments/dd1997-19/eng/1303947308350/1303947444023 (1997).

7. Canadian Food Inspection Agency. DD2002-41: Determination of the Safety of Dow AgroSciences Canada Inc. and Pioneer Hi-Bred International's Insect Resistant and Glufosinate - Ammonium Tolerant Corn (Zea mays L.) Line 1507, http://www.inspection.gc.ca/ plants/plants-with-novel-traits/approved-under-review/decision-documents/dd2002-41/eng/1311872961735/1311873078751 (2002).

8. Glaser, J. A. \& Matten, S. R. Sustainability of insect resistance management strategies for transgenic Bt corn. Biotechnol. Adv. 22, 45-69, https://doi.org/10.1016/i.biotechadv.2003.08.016 (2003).

9. United States Environmental Protection Agency. Subpanel on Bacillus thuringiensis (Bt) plant-pesticides and resistance management, https://archive.epa.gov/scipoly/sap/meetings/web/pdf/finalfeb.pdf (1998).

10. Storer, N. P., Thompson, G. D. \& Head, G. P. Application of pyramided traits against Lepidoptera in insect resistance management for Bt crops. GM Crops \& Food 3, 154-162, https://doi.org/10.4161/gmcr.20945 (2012).

11. Kang, J. et al. Modeling the Impact of Cross-pollination and Low Toxin Expression in Corn Kernels on Adaptation of European Corn Borer (Lepidoptera: Crambidae) to Transgenic Insecticidal Corn. Environ. Entomol. 41, 200-211, https://doi.org/10.1603/ en11133 (2012).

12. Tabashnik, B. E., Mota-Sanchez, D., Whalon, M. E., Hollingworth, R. M. \& Carrière, Y. Defining Terms for Proactive Management of Resistance to Bt Crops and Pesticides. J. Econ. Entomol. 107, 496-507, https://doi.org/10.1603/EC13458 (2014).

13. Siegfried, B. D. et al. Ten years of Bt resistance monitoring in the European Corn Borer: What we know, what we don't know, and what we can do better. Am. Entomol. 53, 208-214 (2007).

14. Siegfried, B. D. \& Hellmich, R. L. Understanding successful resistance management. GM Crops \& Food 3, 184-193, https://doi. org/10.4161/gmcr.20715 (2012).

15. Tabashnik, B. E. et al. Insect resistance to transgenic Bt crops: lessons from the laboratory and field. J. Econ. Entomol. 96, 1031-1038 (2003).

16. Tabashnik, B. E. \& Carrière, Y. Global Patterns of Resistance to Bt Crops Highlighting Pink Bollworm in the United States, China, and India. J. Econ. Entomol. https://doi.org/10.1093/jee/toz173 (2019).

17. Dively, G. P., Venugopal, P. D. \& Finkenbinder, C. Field-evolved resistance in corn earworm to Cry proteins expressed by transgenic sweet corn. Plos One 11, e0169115, https://doi.org/10.1371/journal.pone.0169115 (2016).

18. Huang, F. et al. CrylF resistance in fall armyworm Spodoptera frugiperda: single gene versus pyramided Bt maize. Plos One $\mathbf{9}$, e112958, https://doi.org/10.1371/journal.pone.0112958 (2014).

19. Smith, J. L., Rule, D. M., Lepping, M. D., Farhan, Y. \& Schaafsma, A. W. Evidence for field-evolved resistance of Striacosta albicosta (Lepidoptera: Noctuidae) to CrylF Bacillus thuringiensis protein and transgenic corn hybrids in Ontario, Canada. J. Econ. Entomol. 110, 2217-2228, https://doi.org/10.1093/jee/tox228. (2017).

20. Ostrem, J. S. et al. Monitoring susceptibility of western bean cutworm (Lepidoptera: Noctuidae) field populations to Bacillus thuringiensis Cry1F protein. J. Econ. Entomol. 109, 847-853, https://doi.org/10.1093/jee/tov383 (2016).

21. Gassmann, A. J., Petzold-Maxwell, J. L., Keweshan, R. S. \& Dunbar, M. W. Field-evolved resistance to Bt maize by western corn rootworm. Plos One 6, e22629 (2011).

22. Gassmann, A. J. et al. Field-evolved resistance by western corn rootworm to multiple Bacillus thuringiensis toxins in transgenic maize. Proc. Natl. Acad. Sci. USA 111, 5141-5146, https://doi.org/10.1073/pnas.1317179111 (2014).

23. Ludwick, D. C. et al. Minnesota field population of western corn rootworm (Coleoptera: Chrysomelidae) shows incomplete resistance to Cry34Ab1/Cry35Ab1 and Cry3Bb1. J. Appl. Entomol. 141, 28-40, https://doi.org/10.1111/jen.12377 (2017).

24. Statistics Canada. Nova Scotia leads Atlantic Canada in corn and apple area, https://www150.statcan.gc.ca/n1/pub/95640-x/2016001/article/14802-eng.htm (2017).

25. Pereira, E. J. G., Lang, B. A., Storer, N. P. \& Siegfried, B. D. Selection for Cry1F resistance in the European corn borer and crossresistance to other Cry toxins. Entomol. Exp. Appl. 126, 115-121, https://doi.org/10.1111/j.1570-7458.2007.00642.x (2008).

26. Siegfried, B. D. et al. Estimating the frequency of Cry1F resistance in field populations of the European corn borer (Lepidoptera: Crambidae). Pest Manage. Sci. 70, 725-733, https://doi.org/10.1002/ps.3662 (2014).

27. Tabashnik, B. E., Rensburg, J. B. J. V. \& Carriere, Y. Field-evolved insect resistance to Bt crops: Definition, Theory, and Data. J. Econ. Entomol. 102, 2011-2025 (2009). 
28. Alstad, D. N. \& Andow, D. A. Managing the Evolution of Insect Resistance to Transgenic Plants. Science 268, 1894-1896, https://doi. org/10.1126/science.268.5219.1894 (1995).

29. Bourguet, D. et al. Frequency of alleles conferring resistance to Bt maize in French and US corn belt populations of the European corn borer, Ostrinia nubilalis. Theor. Appl. Genet. 106, 1225-1233, https://doi.org/10.1007/s00122-002-1172-1 (2003).

30. Pereira, E. J. G., Storer, N. P. \& Siegfried, B. D. Fitness costs of Cry1F resistance in laboratory-selected European corn borer (Lepidoptera: Crambidae). J. Appl. Entomol. 135, 17-24, https://doi.org/10.1111/j.1439-0418.2009.01488.x (2011).

31. Pereira, E. J. G., Storer, N. P. \& Seigfreid, S. D. Inheritance of Cry1F resistance in laboratory-selected European corn borer and its survival on transgenic corn expressing the Cry1F toxin. Bull. Entomol. Res. 98, 621-629 (2008).

32. United States Environmental Protection Agency. Biopesticide registration action document Bacillus thuringiensis Cry1F corn, http:// bch.cbd.int/database/attachment/?id=10711 (2004).

33. Zhao, J.-Z. et al. Concurrent use of transgenic plants expressing a single and two Bacillus thuringiensis genes speeds insect adaptation to pyramided plants. Proceedings of the National Academy of Sciences of the United States of America 102, 8426-8430, https://doi. org/10.1073/pnas.0409324102 (2005).

34. Roush, R. T. Two-toxin strategies for management of insecticidal transgenic crops: can pyramiding succeed where pesticide mixtures have not? Philosophical Transactions of the Royal Society of London. Series B: Biological Sciences 353, 1777-1786, https://doi. org/10.1098/rstb.1998.0330 (1998).

35. Canadian Corn Pest Coalition. Bt Corn Products/Traits Available in Canada as of May 2019, https://www.cornpest.ca/bt-corn/btcorn-products-traits-available-in-canada-as-of-may-2019/ (2019).

36. Macdonald, P. \& Yarrow, S. Regulation of Bt crops in Canada. J. Invertebr. Pathol. 83, 93-99, https://doi.org/10.1016/S00222011(03)00059-4 (2003).

37. United States Environmental Protection Agency. White paper on resistance in lepidopteran pests of Bacillus thuringiensis (Bt) plantincorporated protectants in the United States, https://www.epa.gov/sites/production/files/2018-07/documents/position paper_07132018.pdf (2018).

38. Schaafsma, A. W., Meloche, F. \& Pitblado, R. E. Effect of mowing corn stalks and tillage on overwintering mortality of European corn borer (Lepidoptera: Pyralidae) in field corn. J. Econ. Entomol. 89, 1587-1592, https://doi.org/10.1093/jee/89.6.1587 (1996).

39. Abendroth, L. J., Elmore, R. W., Boyer, M. J. \& Marlay, S. K. Corn growth and development. Vol. Bulletin PMR 1009 (Iowa State University Extension, 2011).

40. Guthrie, W. D. In Handbook of Insect Rearing Vol. 2 (eds P. Singh \& P. D. Moore) (Elsevier, 1985).

41. SAS Institute. In SAS/STAT 9.2 User's Guide 112 (SAS Institute Inc., Cary, NC, https://support.sas.com/documentation/cdl/en/ statugprobit/61823/PDF/default/statugprobit.pdf, 2008).

42. Bowley, S. R. A hitchhiker's guide to statistics in biology. Generalized linear mixed model edition., (Plants et al., Inc., 2015).

43. Marcon, P. C. R. G., Young, L. J., Steffey, K. L. \& Siegfried, B. D. Baseline susceptibility of European corn borer (Lepidoptera: Crambidae) to Bacillus thuringiensis toxins. J. Econ. Entomol. 92, 279-285 (1999).

\section{Acknowledgements}

The authors are thankful to the grower cooperators who allowed us to collect $O$. nubilalis on their farms and were willing to assist in this research. We are extremely appreciative to Marianne Pushtai-Carey for supplying Cry1F protein. We thank Gordon (Sonny) Murray for help in finding collection locations and assistance with collecting. Thanks to Samuel Capannelli from the Ontario Ministry of Agriculture, Food and Rural Affairs for creating Figure 1 . This research was not supported by any external funding.

\section{Author contributions}

J.S. and A.S. designed the study. J.S. and Y.F. performed the experiments. J.S. analyzed the data. J.S. wrote the manuscript and prepared the figures. All authors reviewed and edited the paper and critically discussed the results.

\section{Competing interests}

The authors declare no competing interests.

\section{Additional information}

Correspondence and requests for materials should be addressed to J.L.S.

Reprints and permissions information is available at www.nature.com/reprints.

Publisher's note Springer Nature remains neutral with regard to jurisdictional claims in published maps and institutional affiliations.

(c) (i) Open Access This article is licensed under a Creative Commons Attribution 4.0 International

License, which permits use, sharing, adaptation, distribution and reproduction in any medium or format, as long as you give appropriate credit to the original author(s) and the source, provide a link to the Creative Commons license, and indicate if changes were made. The images or other third party material in this article are included in the article's Creative Commons license, unless indicated otherwise in a credit line to the material. If material is not included in the article's Creative Commons license and your intended use is not permitted by statutory regulation or exceeds the permitted use, you will need to obtain permission directly from the copyright holder. To view a copy of this license, visit http://creativecommons.org/licenses/by/4.0/.

(c) The Author(s) 2019 